\title{
Una Isĩ Kayawa: Livro de Cura do Povo Huni Kuĩ do Rio Jordão. Edited by Agostinho Manduca M. Îka Muru and Alexandre Quinet. 2014. Jardim Botânico do Rio de Janeiro and Dante Editores, Rio de Janeiro. 260 pp.
}

\author{
Carlos E. A. Coimbra Jr. ${ }^{1 *}$ \\ ${ }^{1}$ Escola Nacional Saúde Pública, Fundação Oswaldo Cruz, Rio de Janeiro, Brazil. \\ *carloscoimbrajr@gmail.com
}

Received December 18, 2015

OPEN ठACCESS

Accepted January 8, 2016

DOI 10.14237/ebl.7.1.2016.561

Copyright (C) 2016 Coimbra; licensee Society of Ethnobiology. This is an open-access article distributed under the terms of the Creative Commons AttributionNonCommercial 4.0 International Public License (https://creativecommons.org/licenses/by-nc/4.0), which permits non-commercial use, distribution, and reproduction in any medium, provided the original author and source are credited.

Over twenty Kaxinawá (or Huni Kuĩ, their preferred ethnic self-designation, meaning Real People) shamans from various villages dispersed along the Jordão River, near the Brazilian border with Peru, held a series of workshops over the course of two years that aimed to document and exchange traditional knowledge about plants, particularly medicinal, as well as their associated stories and myths. One result of this collective effort is Una Isĩ Kayawa, a nicely produced book that combines the expertise of Huni Kuĩ shamans with that of botanists from Rio de Janeiro Botanical Garden.

Agostinho Ĩka Muru was a famed shaman who, since the 1970s, accompanied his people's saga of migration from rubber plantations (seringais), where they worked under slave-like conditions, back to their traditional territories, which are now officially recognized by the Brazilian government. During these decades, he played a major role in safeguarding Huni Kuĩ cultural traditions, including chants, rituals, graphic designs, cotton weaving technics, foodways, and mythologies. Ĩka Muru wished to perpetuate his people's knowledge in a book, like the "whites" do, as he often stated, so that Huni Kuĩ youth would forever have access to reliable information about key elements of their culture.

In collaboration with botanist Alexandre Quinet from Rio de Janeiro, 21 experts on different plant families from renowned herbaria in Brazil and abroad were invited by Ĩka Muru and other Huni Kuĩ shamans to participate in the project. Through this collective effort involving Indigenous plant experts and botanists, 351 plants types were recognized, collected, and named by the Huni Kuĩ in their native language, Hatxa Kui. Of this total, 109 plant samples were botanically identified and selected for inclusion in the book, accompanied by detailed descriptions of their healing properties, associated curing rituals, preparations, and uses (e.g., ritual bathing, topical applications, eye drops, etc.).

Over the last decade, several important books on the ethnobotany of Indigenous peoples in Brazil have become available. Among the newer releases, I would highlight for its comprehensiveness and richness of description a monographic volume about the Yanomami by anthropologist Bruce Albert and botanist William Milliken (2009; see Welch 2010 for a review). Also, an edited volume by ethnobiologist Moacir Haverroth (2013) encompasses ten case studies focusing on the relationship between Indigenous ethnobotanical knowledge and curing practices, based on research carried out by various authors among different communities in Brazil. A possible common denominator between these two books, as well as other contributions to the ethnobotany of Indigenous peoples in Brazil, is their predominantly, if not purely, academic approach. In most previous work, field investigation was done by academic researchers with the aid of Indigenous guides or plant specialists. The design and writing of such books more closely follows academic conventions, i.e., organization into chapters and subsections in accordance with standard ethnographic or botanical logic. In the case of Una Isĩ Kayawa, the entire project departs from a very different perspective, intermingling 
traditional Huni Kuĩ knowledge of plants with leading -edge botanical science.

Back in the 1970s, as he travelled through rainforest trails to visit Huni Kuĩ communities dispersed along the Rio Jordão valley, Ĩka Muru observed, experimented, and recorded plants and plant knowledge among his own people. He recorded detailed plant descriptions and information about plant habits and uses in notebooks, which he kept in secrecy. In addition, Îka Muru recorded his own memories about the plants he saw during his travels and recollections of oral reports from shamans and plant specialists that lived during his youth. He went about this private project at a time when it was not easy to maintain traditional healing practices and rituals because his people lived under the rule of socalled rubber barons (barões da borracha), who viewed Indigenous cultural traditions and expressions as challenges to their authority (Iglesias 2010).

As a watchful leader, Ĩka Muru worried about the continuity of Huni Kuĩ culture and society in face of the swift social and political transformations, to which younger generations seemed to him to be more vulnerable. In his own words:

[...] we elders know more or less the meaning of each of these species, but these young people, they are now studying. [...] I was concerned, and still am. Because our ancestors knew one hundred percent of what we know.
The elders also studied a lot with them [...]. So, I was concerned about recording these stories. [...] Because this material will no longer be hidden, as it was in the past. (Pages not numbered in Ĩka Muru's opening to the book).

Given this background, I see the book Una Isi Kayawa as more than a rich contribution to Amazonian ethnobotany. It is also the concretization of a dream, Ĩka Muru's dream, to pass his and his peer shamans' knowledge and secrets to future generations of Huni Kuĩ. Shortly after the completion of the final workshop, shaman Ĩka Muru died among his close kin, never seeing the final work in print.

\section{References Cited}

Albert, B., and W. Milliken. 2009. Uribi A: A Terra-

Floresta Yanomami. Instituto Socioambiental, São

Paulo.

Iglesias, M. P. 2010. Os Kaninawá de Felizardo: Correrias, Trabalho e Civilização no Alto Juruá. Paralelo 15, Brasília.

Haverroth, M., ed. 2013. Etnobiologia e Saúde de Povos Indígenas. Núcleo de Publicações em Ecologia e Etnobotânica Aplicada. Universidade Federal de Pernambuco, Recife.

Welch, J. R. 2010. Review of Uribi A: A Terra-Floresta Yanomami, by B. Albert and W. Milliken with G. Goodwin Gomez. Ethnobiology Letters 1:18-19. 